Cahiers du MONDE RUSSE

\section{Cahiers du monde russe}

Russie - Empire russe - Union soviétique et États indépendants

40/1-2 | 1999

Archives et nouvelles sources de l'histoire soviétique, une réévaluation

\title{
Soviet controls on the circulation of information in the 1920s and 1930s
}

Jonathan Bone

\section{(2) OpenEdition \\ 1 Journals}

\section{Electronic version}

URL: http://journals.openedition.org/monderusse/3

DOI: $10.4000 /$ monderusse. 3

ISSN: $1777-5388$

\section{Publisher}

Éditions de l'EHESS

\section{Printed version}

Date of publication: 1 January 1999

Number of pages: $65-90$

ISBN: 2-7132-1314-2

ISSN: $1252-6576$

\section{Electronic reference}

Jonathan Bone, "Soviet controls on the circulation of information in the 1920s and 1930s ", Cahiers du monde russe [Online], 40/1-2 | 1999, Online since 15 January 2007, Connection on 02 May 2019. URL : http://journals.openedition.org/monderusse/3 ; DOI : 10.4000/monderusse.3 


\section{SOVIET CONTROLS ON THE CIRCULATION OF INFORMATION IN THE 1920s AND 1930s}

IF BOLSHEviKs in general understood that knowledge is power, Stalinists institutionalized the adage. Historians have long recognized that Stalin and his supporters used control over information to help them gain, exercise, and maintain power in the USSR of the 1920s and 1930s. Surprisingly, however, there has been little serious investigation of how this deliberate manipulation might have affected the era's archival records. On the basis of recent work in a variety of Russian repositories, ${ }^{1}$ therefore, I should like to offer some initial observations on the ways information was controlled within the pre-war Soviet apparat (Party and state apparatus).

From the apparat's inception, conspiratorial Bolshevik habits (carried over from pre-revolutionary practice) reinforced tendencies normally inherent in bureaucratic settings such that knowledge was subjected to control. Individuals and especially institutions in the subsequent, formative years not only routinely manipulated information for their own proximate reasons. More and more they were required to control it procedurally, as part of the general process of consolidating and administering Soviet rule.

1. Since 1992, I have worked extensively in the following Russian archives: the Rossiiskii Tsentr Khraneniia i Izucheniia Dokumentov Noveishei Istorii (RTsKhIDNI), the Gosudarstvennyi Arkhiv Rossiiskoi Federatsii (GARF), the Rossiiskii Gosudarstvennyi Arkhiv Ekonomiki (RGAE), the Rossiiskii Gosudarstvennyi Voennyi Arkhiv (RGVA), the Rossiiskii Gosudarstvennyi Istoricheskii Arkhiv Dal'nego Vostoka (RGIADV), the Gosudarstvennyi Arkhiv Khabarovskogo Kraia (GAKhK), and the Gosudarstvennyi Arkhiv Primorskogo Kraia (GAPK).

The research and writing of this article were supported by grants from the University of Chicago, a Fulbright-Hays dissertation-research fellowship, a grant from the Social Science Research Council, and by a grant from the International Research and Exchanges Board (IREX) with funds provided by the National Endowment for the Humanities, the United States Information Agency, and the US Department of State. None of these organizations is responsible for the views expressed. 
Specialists in the history of the 1920s and 1930s have paid considerable attention over the years to the increasing censorship of publicly disseminated information. However we have given short shrift to the control of information circulating within the apparat itself. While the Soviet Union still existed this neglect was an honest artifact of restricted archival access. In the relatively open post-1991 era, though, it has continued for what I think have been rather different reasons.

First, although cold-war concerns have not vanished entirely, the social focus that used to be decidedly heterodox now dominates our research. Our prior obsessions with the top end of the Soviet system and its capacity to do harm have yielded to broader interests in Soviet society and in the subtleties of the statesociety interface. ${ }^{2}$ Second, many post-1991 investigators (Russians in particular) have been rather more interested in exhuming the Stalinist past than in the relatively prosaic work of analyzing it in full forensic detail. Given that the former activity must precede the latter, much of the bias is wholly understandable and perfectly normal. Unfortunately, zeal in uncovering repression and other salient secrets occasionally has exceeded attention paid to the provenance and general import of the evidence in question.

Controls on the circulation of information within the apparat can be divided heuristically into three general categories: right-to-know controls, need-to-know controls, and special handling procedures.

What I call "right-to-know controls" involved the consecration of various types of material according to an elaborate, graded system of secrecy classification. Access to these sacred texts was proportionate to standing within the state apparatus. The lower the potential recipient's sacerdotal status, the lower the category of esoteric knowledge that was allowed.

"Need-to-know controls" circumscribed the circulation of information at a given right-to-know secrecy level. They compartmentalized knowledge that was notionally relevant to constituent parts of the state apparatus. In particular, they ensured that bureaucratic paper was directed to specific recipients and that these documents contained only that information thought necessary and/or sufficient for the purpose at hand.

Finally, "special handling procedures" governed the preparation, distribution, and storage of secret materials. Note that none of these generic types of controls were mutually exclusive. Need-to-know targeting often was applied to material already restricted by secrecy classification, further narrowing its circulation.

My eventual intent is to work through all three of these areas systematically. I shall confine myself here mainly to right-to-know controls and some special handling procedures.

2. Among the neo-revisionist graduate students and young professors doing the bulk of the new archival research, social history (or perhaps one ought to say, socially minded history) has attracted increasing numbers of proponents. See e.g. a number of my colleagues' contributions to this issue. 


\section{Right-to-know controls What was classified, and why?}

It was apparent long ago that an unknown but presumably large percentage of Stalin-era documents were classified. It also was obvious that this right-to-know control over information served the post-Stalin Soviet present. That is, it was used to hide anything capable of undermining the official version(s) of history. Exactly what classification may have meant in the Stalinist past, however, has remained nowhere near as clear. We still are relatively unaware of what information circulated in secret order in the 1920s and 1930s and why it got the classifications it did. Neither have we been particularly attentive to how right-to-know controls may have affected the archiving of relevant documents. These matters in fact deserve close attention. Not only do they concern possible source biases in individual research projects. They also help establish the general evidential boundaries within which we can do sovietology.

During the entire Soviet period, a general Party/non-Party distinction underlay all right-to-know controls on information. This was so fundamental it scarcely needed to be or was articulated. Bolshevik notions of vanguard politics dictated that Party-generated information not intended for regurgitation to the masses circulate only within Party circles (thus reinforcing the leaders/led distinction thought necessary, given Russian conditions, for progress towards communism). Thus Party membership always was a prerequisite for access to Party knowledge. ${ }^{3}$

Right-to-know controls in post-1917 Russia also included principles carried over from pre-revolutionary practice. The most obvious of these inheritances was the necessity of restricting the number of people potentially privy to sensitive military information. This was particularly true regarding orders bearing first on the continuing conduct of World War I and later on operations during the Civil War/ anti-intervention campaigns. It also applied to the workings of the Sovet Rabochei i Krest'ianskoi Oborony (SRKO), the emergency cabinet that in practice constituted much of the Bolshevik central government during the desperate early years. ${ }^{4}$ In general, formal military rank was necessary from the beginning for access to operational military information. Certain nominal civilians also had access to nonoperational, defense-related information. ${ }^{5}$

3. Especially in the early 1920 s, this sometimes was indicated explicitly. See e.g. Tainy natsional'noi politiki TsK RKP. Vosproizvedeno po tekstu 1-go izdaniia: Chervertoe soveshchanie TsK RKP s otvetstvennymi rabotnikami natsional'nykh respublik i oblastei $v$ Moskve 9-12 iiunia 1923 g. Stenograficheskii otchet (Moscow: INSAN, 1992), frontispiece. This is a facsimile reproduction of the document's original front cover, which bears the rightto-know admonition Tol'ko dlia partorganizatsii.

4. SRKO was formed on 30 November 1918. In April 1920 it was reconstituted as the betterknown Sovet Truda i Oborony (STO).

5. Military/civilian distinctions were equivocal in the Soviet Union of the 1920s and 1930s because so much was or became connected to the idea of defense. Transport workers, for example, had mobilization duties in addition to their normal responsibilities. Wartime capacity was embedded throughout the manufacturing sector. The medical system was set up in part to 
Another conspicuous case of right-to-know continuity involved the workings of the Vserossiiskaia Chrezvychainaia Komissiia (VChK, Cheka) and its bureaucratic kin. Since the main point of a secret police is secrecy, once the Bolsheviks had decided to emulate the Tsarist state and maintain one the number of people eligible to know what it was up to had to be kept small. There also were a number of unexceptional administrative areas in which pre-revolutionary secrecy was partly relaxed after October 1917 and then quickly reinstated on principle. These included high-level governmental deliberations, state finance, judicial investigations, foreign-policy negotiations, and so on.

With the exception of the tight lid kept on information regarding the Cheka, there was nothing particularly sinister about most of these early right-to-know controls. Neither were they particularly pervasive. Quite a lot of what the Bolsheviks attempted early on they actually discussed and did fairly openly (not infrequently, pour encourager les autres). Finally, neither was there anything strikingly systematic about them. The first post-revolutionary classification regimes appeared more or less independently from each other. Often they borrowed on the basis of need from Tsarist practice.

During the NEP era, the various sets of right-to-know controls that had emerged after 1917 were amalgamated into a uniform classification system. On the Party side of things, principles adopted circa 1920 to control access to Politbiuro Tsentral'nogo Komiteta Vserossiiskoi kommunisticheskoi partii (bolshevik) (Politbiuro TsK VKP(b), Politbiuro) protocols were extended during the next few years to cover all sensitive materials. ${ }^{6}$ On the state side of the apparat, the Vserossiiskii Tsentral'nyi Ispolnitel'nyi Komitet (VTsIK) chancellery circulated in 1924 what seems to have been a first attempt at a systematic documentclassification scheme. Whether this was Russian Republic-specific or a localized version of an all-Union procedure is unclear. Within Russia proper, at least, it went out over then-VTsIK chair M. I. Kalinin's signature and covered the handling of

deal with hypothetical combat casualties. Fodder, grain, meat, and other procurements were made with one eye on the state of military stockpiles, etc. Since a good deal of the peacetime elite metaphorically wore uniforms under its street clothes, the number of nominal civilians potentially privy to non-operational defense information was relatively large

6. Stalin seems to have had much to do with the reforms, though it is not altogether clear that he initiated them. In the late 1910 s he was one of several people charged with organizing the Central Committee's everyday affairs. According to the Hoover Institution's web-page introduction to the Soviet-period archival records it has been microfilming in conjunction with Chadwyck-Healey and the State Archival Service of the Russian Federation (Rossarkhiv): "on 8 November 1919 a Politbiuro minute records Stalin's statement that 'certain information about sessions of the Central Committee, admittedly in corrupt form, somehow reaches our enemies' (RTsKhIDNI, f. 17, op. 3, d. 37). Stalin therefore recommended the establishment of a procedure "which would allow only a few of the comrades to get to know the protocols." See "Archives of the Soviet Communist Party and Soviet State: Catalog of finding aids and documents" (Hoover Institute, 1995). The URL (correct at time of writing) is http: /wwwhoover.stanford.edu/archives/front.html. Click on "Introduction" and scroll to the linked page's paragraph 4. 
paper processed by state executive committees (ispolkomy). ${ }^{7}$ Its principles similarly formed the basis of a later, more extensive classification system.

The first truly comprehensive set of procedures for controlling information on a right-to-know basis evidently appeared in mid-1927. Promulgated in the wake of a document-handling brouhaha by the Cheka's second-generation successor, the Ob"edinennoe Glavnoe Politicheskoe Upravlenie (OGPU), it codified, coordinated, and expanded previous practices. ${ }^{8}$ It also laid down what would serve until the 1940s as the basic classification system for both Party and state. To my knowledge this regime has never before been published or circulated among sovietologists. As a public service I give it here in translation:

Orientation list of matters of top secret (sovershenno sekretno), secret (sekretno), and restricted (ne podlezhashchii oglasheniiu) correspondence.

I. Matters of a military nature.

A. Top secret.

1. Supervisory orders and correspondence on preparation of the army and of the country for mobilization;

2. Mobilization schedules and plans of all state Departments (vedomstva), industry, individual enterprises, and institutions; information connected to mobilization plans on the production capabilities of industry;

3. All materials and correspondence on mobilization schedules and basic orders (osnovaniia), and on development of mobilization plans, and also all remaining mobilization correspondence in any way revealing the general mobilization system, its schedule and most important aspects of deployment;

4. Estimations and norms of mobilization reserves; correspondence containing instructions on mobilization requirements and mobilization attainments;

5. Mobilization requisitions of all types and correspondence on them;

7. A copy is filed in GAKhK, f. r-1228 (Predstavitel'stvo Dal'kraiispolkoma pri VTsIKeMoskva), op. 1, d. 56, 11. 68-69: Sekretno. Tsirkuliarno. (Kopiia). Vsem ispol'nitel'nym komitetam avtonomnykh oblastei, vsem gubernskim i oblastnym ispolnitel'nym komitetam RSFSR. Pravila vvedeniia sekretno deloproizvodstva $v$ obl[astiakh] i gubispolkomakh, a takzhe vo vsekh TsIKakh avtonomnykh respublik. [from:] Pred[stavitel'] VTsIK M. Kalinin, sek[retar'] VTsIK. Moskva. Kreml'. 6 marta 1924.

8. The Cheka was succeeded on 6 February 1922 by the Gosudarstvennoe Politupravlenie (GPU), which was reconstituted on 15 November 1923 as the OGPU. This in turn was liquidated on 10 July 1934 and melded into a reconstituted Narodnyi Komissariat Vnutrennikh Del (NKVD). This version of the NKVD served throughout the rest of the $1930 \mathrm{~s}$ as the umbrella internal-affairs/police organ.

I ran across the document-handling affair while looking for something else in the Khabarovsk archives but unfortunately failed to write down anything substantive about it. I now find I can but dimly recall what supposedly happened. If memory serves: one of the major Commissariats had been discovered handing over documents stamped "secret" to a paper recycler; other examples had turned up where non-secret messages had been written on the obverse of old classified documents and then circulated openly. At any rate, see GAKhK, f. r1228 , op. 1, d. 56, probably somewhere around 11.60-80. 
6. Formation-scheme dislocation and correspondence on the deployment of military units and institutions of all state Departments during mobilization;

7. The quartering schedule and correspondence on billeting troop units in the event of war;

8. Information on the organization of assembly and delivery points with instructions on daily capacity and the length of their operation;

9. Correspondence on the utilization during mobilization of local material means for the necessities of troops;

10. Correspondence on construction and repair work to the extent that it reveals mobilization goals;

11. Extra-estimate (sverkhsmetnye) requisitions and special-purpose StateDepartment budgetary estimates for preparation of equipment that are tied to mobilization preparation; estimates of mobilization monetary expenses;

12. Credits for carrying out war and budget estimates for the initial period of a war;

13. Evacuation plans, materials on them, and correspondence on their development;

14. Description of the work of mobilization organs, correspondence and materials pertaining to experimental and trial mobilizations; inspectorate-run mobilization trials;

15. Matters of the country's military-engineering, air, and military-chemical preparation;

16. Chemical means of attack and defense, consisting of [existing] arms, arms planned for introduction or desired arms (gases, anti-gases, etc.); and means of defense from the airborne enemy;

17. Especially important inventions and proposals; experimental requisitions for new types of weapons from inventions having a top-secret character; design descriptions and budget estimates for these items;

18. Operational-intelligence and informant (osvedomitel'nye) summaries and information;

19. The dislocation of troop units, of the administration, and of the institutions of the [Workers' and Peasants'] Red Army and of Departmental armed guards during wartime; the full dislocation of the Red Army, and of military- and aviation-industry factories in peacetime;

20. The condition and production plans of military- and aviation-industry enterprises;

21. New construction of military and aviation factories;

22. Photo-surveys and plans of fortresses, fortified areas, military ports, explosives warehouses, military- and aviation-industry factories (both factories in toto and production sections of factories), and of technical construction on strategically significant lines of communication;

23. Plans of commercial transport in wartime, material related to them and correspondence on their development;

24. The chart and timetable for the movement of trains in wartime with explanatory notes on it; rail-junction agreements;

25. Plans for the restoration and the destruction of lines of communication and correspondence on them;

26. Mass negative (otritsatel'nye) occurrences in the political and moral condition of troop units, characterized by their disintegration. 


\section{B. Secret.}

1. The organization of mobilization plans and regulations on them;

2. Correspondence on requisitions for military equipment from abroad;

3. Matters of extraordinary protection, connected to carrying out military and exceptional regulations;

4. Objectives of military protection; the condition, numerical strength, and armaments of the latter; the specially important state significance of objectives of Departmental armed protection;

5. The condition of fire protection for military-industrial factories and warehouses of the institutionalized military (voenved, for voennoe vedomstvo);

6. Correspondence preparatory to the promulgation of measures for curtailing civil-aviation flights or changing these flights;

7. Military-topographic maps:

a) On a scale of 1-100,000 (or 2 versts to 1 inch) and larger within the limits of the extended border zone (prigranichnaia polosa) established by the Revolutionary Military Council of the USSR (Revoliutsionnyi Voennyi Sovet (RVS SSSR)) and published after 1 January 1918;

b) On a scale of 1-200,000 (or 5 versts to 1 inch) and larger for fortress regions, fortified areas, ports, batteries, and forts;

c) Of all scales, supplemented with newly designated symbols for special Commissariat of Army and Naval Matters (Narodnyi Komissariat po Voennym i Morskim Delam - Narkomvoenmor) purposes;

8. Individual negative occurrences in the political and moral condition of troop units, capable of leading to their disintegration;

9. a) The dislocation in toto of all units, administration, and institutions of each military region;

b) The dislocation in toto of every individual type of force (rifle, command, artillery, technical units of all specialties, the air force, the fleet);

c) The dislocation in toto of every category of institution and establishment (for example, [the sites of] all institutions of higher learning (VUZy), all warehouses, etc.);

d) The concise dislocation of the Red Army;

10. The dislocation of military and aviation factories individually;

11. General plans for procurement, construction, and major-repair work for the requirements of the armed forces and information on the supply of the latter in all categories of supply and allowance (dovol'stvie) in peacetime;

12. Correspondence on current orders of the institutionalized military to industry in the event they disclose instructions on the scale and fulfillment level of the order/program task for individual industrial sectors;

13. Matters of military shipbuilding and ship repair;

14. Information on equipping military and aviation factories with apparatuses and crucial equipment, giving the possibility of drawing conclusions about factory capacity;

15. The organization and staff of units, institutions, and establishments of the Red Army in wartime;

16. Correspondence on the drafting of Soviet citizens residing abroad;

17. The organization and equipment of concentration and delivery points;

18. Mobilization correspondence with the exception of matters designated as top-secret in [I-A,] point 3; 
19. The allocation of land under military installations (fortresses, hangars, proving grounds, etc.) to the institutionalized military; and the making of structures and the planting of trees called for by defense needs;

20. Matters containing in themselves data having connection both to mobilization readiness and to preparation of all types of transport, but not appearing as elements in the mobilization plan, in agreement with the periodically established Commissariat of Railroads (Narodnyi Komissariat Putei Soobshchenii - NKPS) and Narkomvoenmor lists;

21. Photo-surveys and plans of civilian (grazhdanskie) factories (or of their production sections) in cases where the factories (or their production) are occupied in the manufacture of Red Army armaments.

II. [Matters of] a financial-economic nature.

A. Secret.

1. The export plan in toto and the export in part of individual goods;

2. The import plan in toto and per individual purchases, if the latter point to a percentage relationship to the general plan in toto or to the import in part of individual goods, or else touch on the import of items which are secret;

Note: Pertaining to this last are items having a connection to the fighting capacity of the army, purchases of horses, items purchased for military industry (voenprom) and the Aviation Trust;

3. Correspondence on special imports;

4. The finance plan for exports and imports in accordance with the exposition in points 1-3 above;

5. Preparation of trade, customs, special-rights, sanitary, etc. treaties, conventions, and agreements;

6. Unfavorable information on the quality of goods subject to export;

7. Correspondence on the fight against contraband;

8. Correspondence on preliminary negotiations on major orders abroad for goods and important equipment;

9. Reports of organs abroad, containing in themselves indications: 1) of the organizational forms of [their] work; 2) of the scheduled character and scale of [their] activities;

10. Working up the basic regulations for reviewing customs tariffs and custom-tariff rates;

11. Preparation of concession agreements;

12. Operations for buying and conversion (realizatsiia) of precious metals, gemstones, foreign hard currency, and hard-currency supplies;

13. The state of the scheduled hard-currency supply;

14. Hard-currency resources of banks and economic organs;

15. Hard-currency plans;

16. Correspondence on Soviet banks abroad;

17. Matters of our monetary and hard-currency policies abroad;

18. Correspondence on international settlements of the USSR and on borrowing abroad;

19. Correspondence establishing concrete operational measures for regulating the hard-currency and commodities markets;

20. Secret budget estimates (individually secret articles of Departmental budget estimates) of the Central Executive Committee (Tsentral'nyi Ispolnitel'nyi Komitet SSSR - TsIK), The Council of People's 
Commissars (Sovet Narodnykh Komissarov-SNK SSSR), the Commissariat of Foreign Affairs (Narodnyi Komissariat Innostrannykh Del - Narkomindel), the OGPU, Narkomvoenmor, and others; secret extra-budget requests; bookkeeping re these;

21. Minting coins and preparing paper money per special orders constituting state secrets;

22. Counterfeit money and the struggle against counterfeiters;

23. Correspondence establishing rates proposed for the issue of government bonds, and proposed prices for the realization of bonds and quotation plans;

24. Correspondence on enterprises and property located abroad in which the USSR has a state interest;

25. Manufacture, production, and inventory of platinum and of rare chemical elements, such as radium, vanadium, helium, etc.;

26. Inventions and improvements having state significance;

27. Correspondence on the subscription of specialists from abroad in cases where they are being invited for work bearing a secret character;

28. Correspondence concerning the impossibility of fulfillment by [those] economic organs having Union-level significance and the right to participate in foreign markets of their foreign obligations (in connection with foreign banks and firms).

\section{B. Restricted.}

1. Materials on the preparation of export and import plans;

2. Preparation for the foundation of joint-stock companies bringing in foreign capital;

3. Inquiries and information on credit worthiness;

4. The imposition of prohibitions on capital; the unacceptability of various banks' bills of acceptance;

5. The establishment of budgetary limits and limit policies;

6. Plans for the supply of the domestic market;

7. New deposits of platinum and rare metals;

8. Calculation (kal'kulatsiia) of export goods;

9. Correspondence containing information on unfavorable occurrences in hard-currency and commodities markets.

III. [Material of] a political nature.

A. In agreement with special regulations (soglasno osobykh polozhenii). Correspondence of Party organs and other conspiratorial (konspirativnye) documents.

B. Top secret.

1. Information summaries (svodki) and surveys (obzory) of the OGPU and other surveillance organs;

2. Information and materials on the activities of anti-Soviet parties and groupings, and on the struggle with them;

3. Correspondence on matters of political and economic espionage, and also on methods and measures of the struggle with counter-revolution and espionage;

4. Secret agreements with foreign governments and correspondence on their conclusion; 
5. Reports and individual information on the political and economic state of foreign governments, based on data received from special, restricted sources;

6. Matters of staff and persons working abroad per the line of special Departments;

7. Preparation and fulfillment of secret expeditions and correspondence on them;

8. Correspondence on matters of the arrest and deportation of foreigners and on the exchange of those arrested;

9. The organization of illegal border crossings;

10. Correspondence on investigative matters per articles 58-67 and 71 of the Criminal Code.

C. Secret.

1. Correspondence on matters of administrative deportation and exile;

2. Escaped prisoners and disorders in places of confinement, and hunger strikes (golodovki);

3. Correspondence on investigative matters not designated in point [III-B] 10 above, divulgence of which could damage the course of the investigation;

4. Acts and correspondence on putting into execution death sentences;

5. Correspondence on the conduct of arrests and searches, with the exception of conduct in matters not requiring the observance of secrecy;

6. Preparation for the conclusion and emendation of non-secret political treaties and agreements with foreign governments;

7. Information on preparation on the part of neighboring governments for border conflicts and disturbances in the border zone;

8. Correspondence on change in the principles of state policy connected with emigration in general and with matters of restoration of citizenship (grazhdanstvo) in particular;

9. Data on persons prohibited from entering the USSR;

10. Correspondence on the issue of visas in special order.

D. Restricted.

1. Information on conflicts and disturbances among workers and other strata of the population, not incorporated in information summaries;

2. White-Guardist and foreign literature (books, newspapers, etc.), whose open sale in the USSR is not permitted.

IV. [Material of] a general nature.

A. Top secret.

1. State codes; coded and decoded correspondence; correspondence on codes and on cryptographic work.

\section{B. Secret.}

1. The organization of secret document handling (deloproizvodstvo); procedure for conducting and archiving secret correspondence;

2. [Anything] pertaining to correspondence received from other Departments as secret, when the issue in [the correspondence] that is under discussion has been brought up by [an organization] other than the receiving Department and does not belong in full to [the latter's] jurisdiction. 
C. Restricted.

1. Characterizations and attestation materials on personnel (In the Military Department - secret.)

2. Materials on inspection and revision, not containing information enumerated in the present list as secret.

Source: GAKhK, f. r-1228, op. 1, d. 56, 11. 70-72: [From:] Head of the OGPU Special Section (Nachspetsotdela) Bokii, Head of the 5th Section of the OGPU Special Section Tsibizov, copy, not signed, no date, from context probably May/June 1927.

In practice the above list applied to both Party and state channels. Moreover, it governed not just correspondence in the grammatological sense but communication in general (including electronically transmitted information). However, it contained several noticeable omissions. Operational information and orders within the military proper continued to be governed by an idiosyncratic right-to-know regime that remains obscure. Much OGPU, NKVD, and Narodnyi Komissariat Iustitsii (Narkomiust) material not specified in the list also seems to have been classified on principle. No doubt there were other important lacunae. ${ }^{9}$

Note too that classification terms differing from those specified above were quite common. Most of these right-to-know indicators amounted to variations on established themes. Thus "strictly secret" (strogo sekretno) was equivalent functionally to "top secret" (sovershenno sekretno). The addition of the word "urgent" (srochno) to a given classification indicated pressing temporality rather than any change in intrinsic status. Regarding the common addition "personal" (lichno), it was a need-to-know, information-targeting designation and did not affect right-to-know status.

Only in the case of "not for publication" (ne pechataetsia and its equivalents) does there seem to have been independent meaning. This term normally seems to have fallen somewhere between unclassified and "restricted" (ne podlezhashchii oglasheniiu and its equivalents). Apparently it was used most often to distinguish knowledge potentially available to the public from information meant to be circulated only within the apparat but not otherwise restricted. ${ }^{10}$

9. Classified topics omitted from the list would appear to include: trial proceedings and judicial-system reviews; penal administration; fines and other civil (as opposed to criminal) sanctions; censorship and propaganda; earthquakes, famines, forest fires, floods, and other civil disasters; major epidemics among both the human (plague, typhus, cholera) and farm-animal (glanders, anthrax, infectious anemia) populations; municipalizations and nationalizations; some election-related proceedings including the compilation of voter lists, vote-counting, and recounts; the fixing of tax rates, surcharges, rents and user fees; etc.

10. See for example GAKhK, f.r-137 (Dal'kraiispolkom), op. 3, d. 47 (Sbornik postanovlenii i rasporiazhenii Dal'kraiispolkoma za 1931 god), 11. 421-512: Sistematicheskii ukazatel' postanovlenii D[al'nego] V[ostochnogo] K[raevogo] I[spolnitel'nogo] K[omiteta] za 1931 god. Most of these open-session resolutions are printed in full in accordance with routine procedure. However No. 1067 (25.IX.31 g.), 1281 (12.XI.31 g.), and No. 1333 (28.XI.33 g.) are marked ne pechataetsia while No. 481 (15.V.31 g.), No. 528 (10.VI.31 g.), and three others are designated ne podlezhit oglasheniiu. 
As for what was meant in Section III-A by conspiratorial information, the term originated within the pre-revolutionary Party. It initially had to do with knowledge circulated only within the core group of Bolshevik activists. These elitist connotations were strengthened after the Civil War, when the Party began to grapple with expansion for purposes of peacetime administration. ${ }^{11}$ Following the right-to-know reforms of the early 1920s, information was deemed conspiratorial for one of two related reasons.

First, certain top-level, central bodies were designated "conspiratorial organs." All their bureaucratic paper was classified at least sovershenno sekretno and its handling was made subject to special need-to-know regulations (q.v.). On the Party side of things, the major conspiratorial organs in the 1920s and 1930s were headed by the Politbiuro. Reporting directly to it were the Organizatsionnoe biuro TsK VKP(b) (Orgbiuro), the Sekretariat TsK VKP(b) (Sekretariat), the Prezidium Tsentral'nogo Kontrol'nogo Komiteta VKP(b) (Prezidium TsKK, later the Biuro Partiinogo Kontrol'nogo Komiteta VKP(b)), and the Ispolnitel'nyi Komitet Kommunisticheskogo Internatsionala (IKKI). Leaving aside the institutionalized military, which evidently followed its own idiosyncratic right-to-know system, the conspiratorial state organs notably included the Cheka/GPU/OGPU/post-1934 $\mathrm{NKVD}^{12}$ and Narkomindel. Both of these nominally were subservient to SNK SSSR and practically appended directly to the Politbiuro.

Second, certain highly charged topics were assigned conspiratorial status. Information pertaining to them normally bore a minimum classification of sekretno and was subject to the aforementioned special regulations regardless of venue. Precisely what the conspiratorial topics were is unclear and no definitive taxonomy has turned up. However, they almost certainly corresponded closely to a group of Politbiuro-agenda items assigned so-called "special folder" (osobaia papka) status.

As suggested above, from roughly 1920 on information connected directly to Politbiuro sessions (protocols and attendant documents, including attachments, resolutions, excerpts, submissions by subcommissions and working groups, circulars, etc.) automatically carried a minimum classification of sovershenno sekretno. ${ }^{13}$ However, certain Politbiuro-protocol items were even more restricted. These carried the designation osobaia papka (literally, "special folder"). ${ }^{14}$ They

11. For konspirizatsiia and its consequences see e.g. Andrea Graziosi, The great Soviet peasant war: Bolsheviks and peasants, 1917-1933, Harvard papers in Ukrainian studies (Cambridge: Ukrainian Research Institute, 1996).

12. This requires qualification. In addition to its politicized police-organ responsibilities, the post-1934 NKVD dealt with such mundane internal-affairs matters as civil-sector fire protection. These unexceptional functions do not seem to have been considered conspiratorial.

13. On the automatic classification see O. V. Khlevniuk, A. V. Kvashonkin, L. P. Kosheleva, L. A. Rogovaia, eds, Stalinskoe Politbiuro v 30-e gody: Sbornik dokumentov (Moscow: "AiroXX," 1995): 9 (hereafter Stalinskoe Politbiuro). Politbiuro protocols for the 1920s and 1930s are archived in RTsKhIDNI, f. 17 (TsK VKP(b)), op. 3.

14. Politbiuro-protocol points classified osobaia papka and some of their attendant papers are archived in RTsKhIDNI, f. 17, op. 162. To the best of my knowledge, these osobye papki now are generally accessible to researchers only through the mid-1930s. 
included at a minimum: police-organ matters; Narkomindel, IKKI, and other issues with international-relations implications; defense (this was interpreted broadly); hard-currency questions including import and export plans; and top-level intraParty business. ${ }^{15}$ That is, they were more or less the main administrative concerns of the various conspiratorial organs reporting to the Politbiuro. ${ }^{16}$

While osobaia papka was the highest right-to-know classification known to me to have been employed in the 1920s and 1930s, its use was extremely narrow. It normally applied only to decisions taken in agenda order by the Politbiuro and circulated for informational purposes within that organ.

The Politbiuro publicly, if not privately, was an advisory body issuing no direct orders and having no direct role in governance. Thus osobaia papka decisions (like all its directives) had to be laundered through proxy organs. In general these were the TsK VKP(b) for Party matters plus SNK SSSR and/or STO for state business. Osobaia papka-level decisions normally bore only the Politbiuro's routine sovershenno sekretno classification as they percolated through apparat pipelines. So too did input and follow-up handled by the various subsidiary groups charged with managing such matters. ${ }^{17}$ However, the Politbiuro occasionally forewent the fiction of "asking" proxies to promulgate osobaia papka-level directives. For matters of sufficient urgency and/or gravity it simply issued them itself in the name of the proxy

15. See RTsKhIDNI, f. 17, op. 162, d. 9, 1. 112: Protokol No. 22 zasedaniia PB TsK VKP(b) ot 7.I.1931 g. (osobyi No. ----). Punkt 17/27 (reshenie ot 30.XII.30 g.). O zasedaniiakh Politbiuro (t. Stalin). This marked a short-lived attempt to separate the Politbiuro's normal business (if the term may be used) from osobaia papka agenda items. Stalin's proposal was to discuss the former at sessions on the 5 th, 10 th, and 15 th of the month while restricting sessions on the 10th, 20 th, and 30 th to the latter.

16. Not all osobaia papka items were intrinsically momentous, and the classification sometimes was awarded primarily for procedural reasons. A strikingly banal example is RTsKhIDNI,f. 17, op. 162, d. 12, 1. 170: Protokol No. 82 zasedaniia PB TsK VKP(b) ot 8 ianvaria 1932 g. (osobyi No. ----). Punkt 42/2. O myle (tt. Molotov, Mikoian). This mandated the release from reserve stocks of seven thousand tons of household soap to cover undershipment to Leningrad, Moscow, the Donbass, and other sensitive areas where workers were complaining of goods shortages.

17. The Politbiuro began life in 1919 as a permanent subcommittee of the TsK RKP(b), later the TsK VKP(b). TsK VKP(b) chancellery work devolved in general on its Secretariat, and responsibility for classified information on the Secretariat's Biuro. Thus the Biuro's functions included handling Politbiuro paper.

On 19 March 1926, the Biuro's responsibility for classified information was transferred to a so-called Sekretnyi Otdel (SO) newly formed within the Secretariat. The SO consisted of a number of subsections assigned to the various permanent TsK VKP(b) subdivisions. They were called (unimaginatively) the Politbiuro apparat, the Orgbiuro apparat, etc.

On or around 10 May 1929, the SO was reorganized into seven sectors (sektory). Sector 1 served the three TsK secretaries and their apparaty; Sector 2 served the Secretariat TsK VKP(b) and the Politbiuro; Sector 3 handled documents for the Orgbiuro; Sector 4 dealt with codes and ciphers; Sector 5 kept tabs on the return of conspiratorial documents; Sector 6 was the secret TsK VKP(b) archive; and Sector 7 dealt with communications, stenography, autopen (mashinopis') signatures, and so on.

The SO again was restructured on 13 November 1933. That part of Sector 2 serving the Politbiuro was split off, usurping its parent organ's name and made directly subordinate to Stalin (the remainder was designated the Upravlenie delami TsK VKP(b)). Thus the title SO TsK VKP(b) now referred to a dedicated Politbiuro chancellery handling classified information. With the adoption of a new Party charter early in 1934, the revamped SO was renamed the Osobyi Sektor. However it does not appear to have changed function. It continued to handle the 
organ. In such cases the copy of the decision that was seconded after the fact to the nominal bureaucratic issuer(s) seems to have born osobaia papka status. ${ }^{18}$

Non-conspiratorial organs deliberating conspiratorial topics were required to do so in so-called "closed sessions" (zakrytye zasedaniia). Statutorily, these were meetings, plenums, conferences, etc., in which deliberation of "the most secret matters" (naibolee sekretnye voprosy) was supposed to take place "without secretaries or report-givers" and with the presiding individual responsible for maintaining the session protocol. ${ }^{19}$ That is, physical presence at decisive moments theoretically was restricted to individuals formally vested with decision-making authority and, implicitly, appropriate security clearance.

Sessions that began in normal order could be declared temporarily closed in the event a conspiratorial topic came up, whether accidentally or in agenda order.

Politbiuro's paperwork processing as well as some direct preparatory work and follow-up investigation (proverka). All this was done at the sovershenno sekretno level of classification.

Meanwhile, the bulk of the Politbiuro's preparatory work and proverka devolved on various Politbiuro commissions. Some of these were more or less permanent, e.g. the hugely important Komissiia Oborony (KO PB). Most however were more in the nature of temporary working groups. As far as I know, none of the information channeled through any of these was classified osobaia papka. Instead it appears to have been designated sovershenno sekretno.

Note however that on 14 April 1937 the Politbiuroconsolidated the most pressing parts of this input/follow-up work among two standing commissions. One, consisting of Stalin, V. M. Molotov, L. M. Kaganovich, and N. I. Ezhov, was assigned to handle osobaia papka-type topics including matters of foreign policy. It also received authority to decide matters in the name of the Politbiuro "in cases of special urgency." The other, consisting of Stalin, Molotov, V. Ia. Chubar', A. I. Mikoian, and Kaganovich, was to deal with urgent administrative?! (khoziaistvennye) matters. It is quite possible that at least the first of these commissions operated routinely at the osobaia papka-level. Unfortunately, verification is impossible because the records evidently are in the so-called "Presidential Archive" (Arkhiv Prezidenta Rossiiskoi Federatsii - APRF) and thus are off limits to researchers. See RTsKhIDNI, f. 17, op. 3, d. 986, 11. 16-17: Protokol No. 48 zasedaniia PB TsK VKP(b) ot 16 aprelia 1937 g. Punkt 53 (oprosom chlenov PB ot 14.IV.37 g.). Opodgotovke voprosov dlia Politbiuro TsK VKP(b), given in Stalinskoe Politbiuro: 55.

18. Apart from the Politbiuro, STO circa 1931 was using the designation osobaia papka. See e.g. GARF, f. 5674 [STO], op. 1, d. 46, 1. 58: Protokol No. 22 zasedaniia Soveta Truda $i$ Oborony ot 16 avgusta $1931 \mathrm{~g}$. O zakreplenii raionov dlia eksporta pshenitsa. This is marked "for decision, see special folder" (reshenie sm[otrite] osobuiu papku).

So too was SNK SSSR circa 1937. See e.g. GARF, f. 5446 (SNK SSSR), op. 57?! [delo and list not given]: sov[ershenno] sekretno (Osobaia papka). Postanovlenie No. 1428-326ss Soveta Narodnykh Komissarov Soiuza SSR i Tsentral'nogo Komiteta VKP(b). O vyselenii koreiskogo naseleniia iz pogranichnykh raionov Dal'nevostochnogo kraia. 21 avgusta 1937 goda. [over:] Predsedatel' Soveta Narodnykh Komissarov Soiuza SSR V. Molotov, Sekretar' Tsentral'nogo Komiteta $V K P(b)$ I. Stalin, given in Mezhdunarodnaia konfederatsiia koreiskikh assotsiatsii (SNG), Moskovskii mezhdunarodnyi universitet, Belaia kniga o deportatsii koreiskogo naseleniia Rossii v 30-40kh godakh. Kniga pervaia, avtory-sostaviteli: Professor Li U Khe, dotsent Kim En Un (Moscow: "Interpraks," 1992): 64-65.

Both of these examples probably reflect osobaia papka resolutions directly issued by the Politbiuro in the name of proxy organs. My educated guess is that Politbiuro provenance is similarly true for all osobaia papka material that may be archived in STO, SNK SSSR, and other top-level fondy.

19. See RTsKhIDNI, f. 17, op. 3, d. 740, 11. 13-15: Prilozhenie No. 2 k p[unktu] 17 pr[otokola] No. 80 (zasedaniia Politbiuro TsK VKP(b) ot 16 maia 1929 g.). O Konspiratsii (utverzhdeno Politbiuro TsK VKP(b) 16.V.1929 g. - Prilozhenie. Iz postanovleniia Politbiuro TsK ot 5.V.27 g. O pol'zovanii sekretnymi materialami, razdel B punkt 11, in Stalinskoe Politbiuro: 75-77. A full translation of this document excerpt appears on pages 17-19 of this article. 
Common practice however was to segregate meeting agendas into parallel deliberations. One set of these split sessions served for routine business and a second, closed set took up conspiratorial topics. ${ }^{20}$ Note however that zakrytye zasedaniia not infrequently also considered non-conspiratorial topics. Moreover, though closed-session protocols always were classified, input, output, and/or follow-up to non-conspiratorial agenda points from them often bore no direct indication of special provenance. Typically it was indistinguishable from the bureaucratic paper generated by routine sessions. One other aspect of the Orientation List deserves additional explanation. According to section IV-B point 2 , anything engendered by correspondence that some other organ had classified sekretno was supposed to retain that classification unless the recipient had both full jurisdiction over the matter and some reason to alter it. In practice, the principle underlying this prescription had something approaching Newtonian universality. I call it the Law of the Conservation of Classification: outgoing information routinely went up (or across) channels at whatever the level of secrecy a direct request for it had borne coming in. This happened whether or not anything in the information itself warranted even minimal classification..$^{21}$

Sovietologists who care about such things have been struck for some time by the apparent overclassification of so many Stalin-revolution documents. Some of this no doubt occurred because paper-processing functionaries and other apparatchiki

20. Closed sessions often were identified explicitly, as for example (from the Smolensk Archive) VKP-44/21-22: sekretno. Protokol No. 48 zakrytogo ob"edinennogo zasedaniia Biuro Kaluzhskogo Gubkoma VKP(b) i Prezidiuma GKK ot 6-go ianvaria $1929 \mathrm{~g}$. However, they could be less obviously labeled. The closed convenings of STO SSSR are a notable example. These were known as Managing Sessions (rasporiaditel'nye zasedanii; RZ STO) through 23 December 1930, when the Komissiia Oborony pri PB (Stalin, Molotov, K. E. Voroshilov, V. V. Kuibyshev, and G. K. Ordzhonikidze, with L. M. Kaganovich at first a de facto and later a de jure member) took over their function and began direct issue of conspiratorial-topic orders in the name of STO. This fiction was maintained until 27 April 1937, when STO was abolished altogether and the KO PB restructured as the Komitet Oborony pri SNK SSSR (also KO).

21. Here is a typical example from GARF, f. 5515 (Narodnyi Komissariat Truda SSSR; NKTrud), op. 33s (Sekretariat Kollegiia NKTrud - sekretnaia chast'), d. 53:

A) The seminal request was 1. 7: sekretno. srochno. Narkomtiazhprom [NKTP] SSSR $t$. Stoliarovu. [from:] Zam[estitel'] Nachal'nika Upravleniia Kadrov NKT SSSR Kozlov, Inspektor Gomovich. Narodnyi komissariat truda Soiuza SSR No. 17s, 5 ianvaria $1933 \mathrm{~g}$. This asked NKTP SSSR for data from some of its subsidiary trust organs in Dal'nevostochnyi krai: Aviastroi (a hydroplane-assembly plant under construction at Komsomol'sk-na-Amure), Soiuzvodostroi (a dam and water-supply reservoir for Vladivostok), Ogneuportsemstroi (a Portland-cement kiln at Spassk, on the Ussurii River between Khabarovsk and Vladivostok), etc. It sought data on expenses on recruitment and in-transfer of workers for 1932, outlay targets for 1933, the state of recruitment agreements with kolkhozy and edinolichniki, material conditions at the job sites, etc. There is nothing in the otherwise mundane document (or for that matter, the entire delo) to indicate it, but all these projects had crash-priority defense significance ratified by Stalin himself. This hidden military angle apparently supplied the original rationale for classification (presumably under I-B-11 in the 1927 Orientation List).

B) NKTP ordered the Moscow representations of the trusts in question to respond directly to NKTrud as well as to it. The directive went out five days later as 1. 18: srochno-sekretno. Pochto-telegramma No. 458s iz Tsentr[al'nogo] Sektora Truda NKTP SSSR. [from:] Nachal'nik Tsentral'nogo Sektora Truda NKTP SSSR Figatner. 10.I.33 g. [copy archived by NKTrud as:] No. 285. 
found it prudent, in a climate of increasingly rampant paranoia, to err on the side of caution. As Sheila Fitzpatrick once suggested, it also may have been an expedient way of flagging important items in an accelerating paper avalanche. ${ }^{22}$ Regardless of how much these factors may have come into play, however, the Orientation List plus the Law of Conservation of Classification seem to have been the methods behind much of the apparent madness. I concede that the apparat was no better at carrying out proper document-handling procedure (deloproizvodstvo) in the late 1920 s and 1930s than at fulfilling anything else in due order. Still, I contend that secrecy stamps were applied far more rationally than previously supposed.

\section{General implications of right-to-know controls}

The right-to-know controls outlined above have a number of broad sovietological implications. For one thing, certain military and secret-police matters apparently warranted a higher level of classification (sovershenno sekretno) than anything of a financial/economic nature. On the presumption that secrecy level corresponded to general epistemological importance, this strikes me as an interesting commentary on Stalinist priorities: the USSR's economic transformation evidently had less importance than the defense of the Revolution against notional enemies, whether foreign or domestic. The List can be read as a kind of demonological guide to Bolshevik bogeys, sometimes yielding surprising, counter-intuitive results. Thus counterfeiting (II-A-22, rated sekretno) apparently was a more serious specter by the late 1920s than White Guardist literature (III-D-2; ne podlezhashchii oglasheniiu), and so on.

Moreover, the Orientation List shows not only the range of information kept secret in the late 1920s and 1930s but also (by implication) the revelatory limits of non-secret paper from those years. It provides us some quite solid guidelines to the sorts of considerations differentiating the hidden side of the emerging Stalinist system from its public facade. Knowing approximately where previously available evidential knowledge leaves off and having a well-grounded topical sense of what we are likely to encounter in still-unexplored secret files should contribute enormously to our future research.

C) The responses from the trusts maintained NKTrud's original classification of sekretno but were wholly banal in content. See for example 1.20: srochno-sekretno. [to:] NKTP Tsentral'nyi Sektor Truda/kopiia NKT[ruda]-SSSR. [from:] SSSR NKTP Soiuzvodostroi sekretnaia chast' [in response to:] NKTruda No. 16/s [received via NKTP on:] 25.I.33. Anyone encountering the body of this message out of context might wonder why it had ever been classified. All it said was that the reservoir project was planning to bring in workers by passenger train at average cost of 363 rubles a head, including a 50-ruble wage advance for household startup, and would pay them at a rate 1.2 times that of the all-Union norm.

22. See Sheila Fitzpatrick, "Introduction: Sources on the social history of the 1930s. Overview and critique," in Sheila Fitzpatrick, Lynne Viola, eds, A researcher's guide to sources on Soviet social history in the 1930s (Armonk: M. E. Sharpe, 1989): 3-25, here 5. 


\section{Special handling procedures}

The right-to-know regime outlined above was a set of restrictions designed to limit the number of persons potentially privy to certain knowledge. To help preserve this secrecy, the preparation, physical distribution, and storage of classified information were governed by measures I call special handling procedures. These were codified preliminarily in 1927 by the OGPU in conjunction with work on the right-to-know controls issued as the Orientation List. Ratified by the Politbiuro, they formed the basis for the "special regulations" for conspiratorial material specified in section IVB point 2. Here in translation are the relevant sections of the resolution in question:

Proceeding from the past-proven principle that secret matters should be known only by those who absolutely have to know them, with the aim of securing maximum conspiracy in [our] dealings and in the use of secret materials, it is considered necessary:

$[\ldots]$

B. With regard to the circulation of conspiratorial documents.

1. Only comrades to whom they are addressed may acquaint themselves with excerpts from Politbiuro protocols (a single institution may be sent only a single excerpt, with an indication of all addressees located in the given institution).

2. The period for returning Politbiuro and Central Committee Presidium protocols is established at no more than 3 days after the day of receipt.

3. Excerpts from Politbiuro protocols are subject to return no later than within a 7-day period. Excerpts from osobye papki are subject to return within 24 hours.

Note: Narkomindel, Voenved, OGPU, and IKKI are permitted retention of materials for a more prolonged period, on the personal responsibility of the head of the institution.

4. To reiterate, especially secret documents should be circulated not to the address of the institution, but personally (with the inscription "personal only" (tol'ko lichno) on the envelope).

5. Identical directives directed to institutions at a [single] location are sent only to one address.

6. The obligatory numbering of copies of circulated materials is reiterated.

7. Coded messages and materials of the Politbiuro with the inscription "personal" (lichno) shall be opened only by the addressee.

Note: comrade Tovstukha ${ }^{23}$ is directed to regularize the technique for delivery of materials.

8. The heads of institutions are obliged to organize especially strict and careful control over the timely return and destruction of circulated conspiratorial materials.

9. It is established as a rule that materials for sessions of inter-Departmental and other commissions considering secret matters shall be circulated

23. I. P. Tovstukha, formerly an assistant to the director of the Institut V. I. Lenin in Moscow, from 1926 to 1930 head of the Secret Section (Sekretnyi Otdel) of the Central Committee Secretariat, later deputy director of the Institute of Marks-Engels-Lenin in 1930 and 1931 (i.e., assigned to Party archival work), died 1935. 
only to those members of the commission who should know the matter in full. The representatives of various Departments and institutions shall be circulated only that part of the materials directly concerning them.

10. The return to the commission Chair of secret materials circulated per commission agenda, promptly after making a decision on the relevant matter, is established.

11. All institutions, and equally all commissions, are required to consider the most secret matters in closed sessions without secretaries and reportgivers, with the protocol kept by the presiding individual.

12. It is considered necessary to keep to a minimum the quantity of circulating informational material, and to circulate to comrades only what is necessary for them for work.

$[\ldots]$

C. Regarding the storage, circulation, and sending of conspiratorial materials.

1. The rule [against] keeping conspiratorial documents in lodgings and in institutions is reiterated.

2. The rule forbidding the sending and transit of secret documents of the Central Committee, OGPU, [Narkomindel], and IKKI except via diplomatic pouch or OGPU courier service ${ }^{24}$ is reiterated.

Note: Exceptions to this rule can be made by decision of the Central Committee Secretariat.

3. Keeping secret materials of the Central Committee, OGPU, [Narkomindel], and IKKI in personal archives is categorically forbidden. The Secret Section of the Central Committee is obliged to demand, within a period of two months, secret Central Committee materials from all comrades having them. ${ }^{25}$

F. On officials carrying out secret work.

As for crimes regarding secret matters, all institutional and organizational officials carrying out secret work are liable for judgment in extra-judicial order.

G. On procedure for realizing the present measures.

1. All institution heads are obliged to carry out all of the aforementioned measures in a timely manner. Hereafter, careful attention is to be given to procedure for the storage, for the circulation, and for control over the return and use of conspiratorial documents.

2. The OGPU (comrade Bokii) ${ }^{26}$ is instructed to monitor the correct use of codes by institutions and individuals having them.

24. The Fel'degerskii Korpus OGPU. This armed-courier service evolved out of the Tsarist Army's dispatch unit, which bore the name from 1796 to 1917, and then the Red Army's version of the same. In the post-Civil War Soviet state, it was administratively a division of the GPU/OGPU/post-1934 NKVD; apparently it was supposed to revert from quasi-civilian to full military status in the event of war.

25. As was the case with most (if not all) attempts to impose administrative discipline on top Party personages, this rule was not always respected in practice.

26. G. I. Bokii, born 1879, Party member from 1900, OGPU Collegium member from 1923, repressed 1937. 
3. Control over the realization of the aforementioned decisions is laid on the OGPU (comrade Bokii), ordering it in 1.5 months to present to the Politbiuro a report on the realization of the present resolution.

4. The Central Control Commission is requested to carry out a decisive struggle with comrades who are disseminating secret decisions, and with every sort of rumor, gossip, etc. of a political nature.

Source: RTsKhIDNI, f. 17, op. 3, d. 740, 1l. 13-15: Prilozhenie No. 2 k p. 17 pr. PB No. 80 (zasedaniia Politbiuro TsK VKP(b) ot 16 maia 1929 g.). $O$ Konspiratsii (utverzhdeno Politbiuro TsK VKP(b) 16.V.1929 g. Prilozhenie. Iz postanovleniia Politbiuro TsK ot $5 . \mathrm{V} .27 \mathrm{~g}$. O pol'zovanii sekretnymi materialami. ${ }^{27}$

These prescriptions were amplified in 1929 as part of a campaign to isolate notional Right Oppositionists. They evidently remained in effect until information handling was put on a wartime footing in the early 1940s. ${ }^{28}$ In the meantime, a number of the principles originally applying to conspiratorial information were applied by extension to the handling of non-conspiratorial secret information. The whole business was knotty, even by the perverse standards of the 1930s. Disentangling all of its myriad strands will require extensive additional research for which I have neither time nor money nor (at present) a burning desire. However, I would like to elaborate on a few commonalties bearing on archival holdings.

To begin with, Stalinist bureaucratic entities as a rule either had some equivalent of a subordinate chancellery section assigned to information services or else shared such a secretariat. Many of these bodies never dealt in routine order with classified materials. However, those regularly working with secret as well as non-secret information contained individuals or subsections specially cleared for the level of classified material expected to come their way. ${ }^{29}$ In cases where the amount and/or classification level of secret information was great (e.g. for the conspiratorial organs), the entire chancellery might have had special clearance. ${ }^{30}$

27. Translated from the Russian version in Stalinskoe Politbiuro: 75-77.

28. For the amplification see Prilozhenie No. $2 \mathrm{k}$ p[unktu] 17 pr[otokola] PB No. 80. O Konspiratsii (Utverzhdeno Politbiuro TsK VKP(b) 16.V.1929 g.) in Stalinskoe Politbiuro: 75. This came out of an explicitly anti-oppositionist resolution of the April 1929 joint TsK/TsKK plenum. The decree mandated "special measures [...] which exclude the possibility that Trotskiists may be informed about Central Committee and Politbiuro affairs" (ibid.: 77). The major change from the 1927 procedures was the elimination of so-called 2nd-category proxies (q.v.). The decree also ordered the reverification of clerical workers processing material at this level (1st category proxies and SO TsK VKP(b) workers).

29. By way of illustration, the Kollegiia NKTruda SSSR handled both classified and nonclassified documents. Within it was a Sekretnaia chast' responsible for the classified paperwork. See GARF, f. 5515, op. 33s.

30. For example, the Dal'kraiispolkom's permanent Representation in Moscow (Predstavitel'stvo Dal'kraiispolkoma pri VTsIKe-Moskva) functioned mainly as a clearing house for Kremlin-level, state-sector material sent to and from the Far East. All of this information was classified sekretno or higher. Thus the Representation's chancellery lacked a separate secret section. See the explanatory notes to GAKhK, f. r-1228, op. 1. 
Special clearance for chancellery workers originally was divided into two broad categories. One group consisted of members of the SO Secretariat TsK VKP(b) and its successors, plus so-called "first-category proxies" (doverennye po 1-i kategorii). These last were essentially secretary-deputies serving under conspiratorial-organ members and candidate members. This group of people had the right to receive, unseal, and process conspiratorial-status documents. A much larger group of socalled "second-category proxies" (doverennye po 2-i kategorii), evidently secretaries scattered through the apparat, functioned in the 1920 s as a kind of poste restante service for conspiratorial-status paper. That is, it had the right to receive and hold these documents but not the right to unseal or process them. Secondcategory proxies however were eliminated in 1929-1930.

One important sovietological implication of the vetted chancellery/proxy system stems from the fact that virtually all inner-circle Bolsheviks had multiple administrative responsibilities. They thus had multiple possible addresses via which they might send and receive highly classified paper. Ian Borisovich Gamarnik, to take one example from my own research, was in the 1930s simultaneously a member of the Orgbiuro, a Central Committee member, Stalin's personal plenipotentiary in Dal'nevostochnyi krai, Voroshilov's deputy in Narkomvoenmor, deputy chair of Revvoensovet SSSR (until 1934), head of the Red Army Political Administration (Politupravlenie RKKA), and a member of any number of temporary inter-organizational commissions dealing with militarypreparedness topics. Since Gamarnik operated on the principle that the chancellery at hand was the chancellery to use, conspiratorial correspondence to/from him (including telegrams to/from Stalin) is here, there, and everywhere.

What is true for Gamarnik must be so also for Mikoian, Kaganovich, Voroshilov, Andreev, Rudzutak, Ordzhonikidze, Kuibyshev, Kalinin, et al. (though not necessarily so for Stalin and perhaps Molotov). On the assumption that these men probably did not save all communication with each other for Politbiuro and Central Committee meetings, much high-level policy debate may in fact be out there, waiting to be pieced together from perhaps dozens of disparate sources.

Finally, special handling procedures also were used to preserve secrecy while classified information was in transit. Soviet secrets circulated via three basic methods. First, as mentioned above, hard copies of conspiratorial documents circulated domestically in sealed packets carried by special couriers from the socalled Adjutant Corps (Fel'degerskii Korpus). These armed messengers had special clearance to handle such material but were strictly forbidden to unseal the packets and examine their contents. Second, indirect electronic transmissions (telegrams, cables, radiograms, and the telephone-delivered text messages known as telefonogramy) were supposed to be handled by specially vetted operators..$^{31}$ Third,

31. This could present problems when messages required retransmission due to distance. Relay stations needed to know in advance that highly classified material was coming through to ensure that the proper dispatchers would be on duty. For example: Gamarnik was in Dal'nevostochnyi krai early in 1932 during one of his stints as Stalin-appointed head of a task 
direct voice-link discussion of classified topics was supposed to be made only over secure telephone lines or frequencies.

The third of these methods of transmitting classified information is somewhat problematic sovietologically. As Dmitrii Volkogonov showed in Triumf i tragediia. Politicheskii portret I. V. Stalina v 2-kh knigakh (Moscow: Izdatel'stvo Agenstva pechati Novosti, 1989), particularly in vol. II, part 1, Stalin in his capacity as wartime Generalissimo was an inveterate micromanager capable of wallowing in minutiae and accounting for an enormous paper output. However it is at least possible that Stalin orchestrated certain matters via face-to-face meetings, direct telephone calls, and/or perhaps voice-radio connection. Orders and information transmitted verbally being inherently ephemeral, no significant hard evidence may ever have existed of his direct authorization for any given course of action.

Credible indirect evidence of 1930s reliance on voice-link connection between the Kremlin inner circle (including Stalin) and anointed envoys in the field exists in Rossiiskii Gosudarstvennyi Voennyi Arkhiv (RGVA, f. 9 (Politupravlenie RKKA), op. 29s, d. 145). This hugely revealing delo consists of several hundred coded telegrams (shifrovki) dispatched to and from Ian Gamarnik during his three separate stints in the Far East in 1932 and 1933 as Stalin's personally appointed plenipotentiary. The telegrams began when Gamarnik passed beyond Irkutsk on his eastbound railway journeys and ended when he attained Irkutsk on his way back to Moscow. This seems to have been because Lake Baikal marked the eastern limit of secure-line telephone communication at the time.

\section{Classified archival holdings}

Classified documents not in transit were supposed to be kept under separate lock and key within the bureaucratic offices using them. This enforced physical segregation was supposed to be preserved to the extent possible when the records eventually were archived. Mistakes happened and classified paper sometimes was mingled into nominally non-secret holdings. ${ }^{32}$ However, although after-the-fact

force. On April 12, that year he telegramed V. V. Kuibyshev in Moscow on the catastrophic status of the region's food supply. The lengthy message was coded and bore the designation top secret (sovershenno sekretno). Archived along with the original, uncoded text is material on how the encrypted message was sent to the Kremlin. This includes the names and ranks of the OGPU telegraphists who sequentially passed on the missive. See RGVA, f. 9, op. 29s, d. 165, 11. 117, 127-130.

32.GAPK, f. r-1518 (Kollektsiia dokumentov Dal'kraiispolkoma), for example, contains minimally indexed paper from the Dal'kraiispolkom Presidium. It was the private document cache of one t. Petrov, a member of the Prezidium DKIK during the 1930s and (prior to his 1938 execution) sometime head of the Primorskaia Oblispolkom. The fond has only one opis', all but one of the dela in it unclassified. The majority of the documents in the unclassified dela are mundane postanovleniia promulgated in normal working order. However, haphazardly interpolated are a number of (thoroughly banal) resolutions marked restricted (ne podlezhit oglasheniiu). I also found one resolution marked "secret" (sekretno) in the unclassified dela (it dealt with the quite non-momentous topic of reducing motor-vehicle accidents). Evidently, Primorskii krai archivists found the physical segregation after the fact of such scarcely momentous 
effort to find and correct filing errors sometimes was proportionate to the degree of secrecy involved, Soviet-period archivists went to considerable lengths to effect maximum segregation of classified records.

Classified material received by archives was segregated physically in two principal ways. One method basically entailed storing it in discrete secret fondy, the other separating it at the opis' level and keeping it in compartmentalized, secret sections of normal holdings.

\section{Spetsfondy}

Paper from conspiratorial organs and other bureaucratic entities whose entire oeuvre was classified was archived in discrete, secret groupings I call spetsfondy. Note that "bureaucratic entity" could mean one or more wholly secret subsections of a given organ, secret or otherwise, provided the amount of classified material requiring storage was large enough or restricted enough to warrant segregation. ${ }^{33}$ Spetsfondy were assigned unique identification/ retrieval numbers not appearing in reading-room card catalogs, putevoditeli, or other finding aids made available to researchers. ${ }^{34}$ On occasion the spetsfond number could also carry a postscript indicating special-handling status, often a lower-case Cyrillic "s" for sekretno. ${ }^{35}$

Spetsfondy publicly did not exist during the Soviet period. At many archives, traces of this pretense unfortunately have persisted into the post-Soviet present. Retrograde views on the right to know are holding back the compilation and distribution of new finding aids listing formerly secret holdings. Continuing lack of candor can make it hugely difficult even to figure out where a desired set of classified records was reposited, let alone come up with fond numbers and other retrieval koordinaty for an attempt to work with the documents.

information not worth the effort. During the Soviet period they controlled access to the classified documents in the fond by the expedients of making browsing forbidden and strictly enjoining researchers to look only at pre-approved listy.

33. Concrete examples of this are hard to find in regional archives I have worked in. I have run across only one apparent exception. GAKhK, f. r-353 (Dal'nevostochnaia kraevaia planovaia komissiia, intermingled with post-1938 documents of the Planovaia komissiia Khabarovskogo kraiispolkoma), op .3s, d. 11, "Perspektivnyi plan osvoeniia raiona vostochnoi chasti BaikaloAmurskoi Magistrali 1933 g.," is listed in the opis' as "na sekretnoi khran. v r. 1903s." Evidently there is a spetsfond which contains planning-commission materials requiring segregation, perhaps from the so-called sektor oborony or from a subsection doing contract work for the NKVD.

34. Some examples of spetsfondy: At GARF, f. 4042 is the Main Administration of Local Places of Detention of the People's Commissariat of Internal Affairs of the RSFSR (Glavnoe Upravlenie Mestami Zakliucheniia NKVD RSFSR); f. 9414 is the principal GULag/ Glavupravlenie Lagerei NKVD/MVD SSSR file, containing among other things records of the organ's Secretariat, etc. They were classified unitarily.

35. See for example Rossiiskii Gosudarstvennyi Istoricheskii Arkhiv po Dal'nem Vostoke, RGIA-DV, f. 3625s (Upravlenie Baikalo-Amurskogo Ispravitel'no-Trudovogo Lageria NKVD-g. Svobodnyi). 
Those of us with infinite time, money, and patience can always obtain introductions, hie themselves off to various archives, request consultations, and inquire in person about their desiderata. However, even the best, most forthcoming staff at a given archive may be genuinely clueless as far as spetsfond holdings elsewhere and progress can be laborious. By way of personal example, I have put nearly three years of intermittent effort into tracking down the spetsfondy for the OGPU/KGB Border Forces during the 1930s and have yet to see a document. My quest has involved both trying to figure out whether the records are in the notoriously user-unfriendly Tsentral'nyi Arkhiv Ministerstva Bezopasnosti Rossiiskoi Federatsii (TsAMBRF) - they aren't - and hunting in alternative locations.

The difficulties of tracking down spetsfondy are compounded by the ongoing sequestration of material in APRF, a process that for us sovietologists resembles watching black holes engulf the known universe. Worse, it turns out that bungling, space considerations, wartime evacuations, and other factors may have dispersed spetsfondy among non-Presidential archives that theoretically should not have them. For example, while looking for the 1930s Border Forces files I inadvertently uncovered the occupation-force records for post-WW II East Germany. They are commingled with the WW II records of the Belorussian and Ukrainian-front SMERSH counterintelligence-unit documents in RGVA, f. 32975 (untitled), op. 1s (Upravlenie vnutrennikh voisk MGD v Germanii ianvaria 1947-marta 1953/MVD maia 1946-ianvaria 1947). Apart from anything else, one reason no one seems to have worked with either of the latter sub-collections is that RGVA is supposed to contain no post-1941 material.

Moreover, my experience has been that even when one is morally certain a given archive must hold a particular spetsfond it may be difficult to prove it in practice. Almost always there is the catch-22 of classified material to overcome: you frequently have to know what's available to be able to order it but you have to order it to find out what's available. When consultations with staff at your target archive come up empty there is no way to tell whether denials that material is present are disingenuous or real.

I should add that the stratagem of requesting opisi for fondy whose numbers are missing from finding-aid sequences doesn't work well. For one thing, obvious trolling expeditions for spetsfondy and other classified "dirt" may annoy archivists. Second, it appears that most lacunae in fond lists are real and have resulted from the loss, merger, transfer, etc. of documents over the years..$^{36}$ Moreover, those gaps that

36. For example, RGAE reportedly houses 1,945 fondy of all types, including spetsfondy, personal document collections (lichnye fondy), partially classified fondy, and unclassified fondy. The 1994 guide to the archive lists unclassified fondy, 1,574 of them. However, GARF's fond number sequence runs from 2 up to at least 9,603. Thus there are many lacunae, such as the 641-number gap between f. 921 (Mel'nichnyi otdel Narkomvnutorga SSSR i ego likvidatsionnaia komissiia) and f. 1562 (Tsentral'noe statisticheskoe upravlenie pri Sovete Ministrov SSSR). Most of these evidently resulted from bureaucratic reorganizations and consequent internal shifting of files. Soviet archives did not recycle numbers that had once been assigned; new fondy or fondy formed out of existing fondy were assigned new numbers at the tail 
are only apparent often turn out to designate odd-lot bits of banal paper that archivists haven't had the time or the inclination to deal with. ${ }^{37}$

\section{Spetspodfondy}

What I call spetspodfondy were created from the classified portion of documents archived by bureaucratic entities processing both secret and non-secret paper. ${ }^{38}$ These were assigned the same basic fond number as the corresponding non-classified paper, with a postscript often added to indicate special storage and handling status. This postscript typically was a lower-case Cyrillic "sch" for sekretnaia chast' 39

Whereas spetsfondy were hidden altogether from public view, it is important to remember that spetspodfondy were merely the classified opisi from fondy normally appearing in finding aids. Some of the most important central spetspodfondy from the 1920s and 1930s evidently have been sequestered in APRF and now may be wholly separated from their non-classified parent holdings. ${ }^{40}$ However, my impression is that most of this type of classified paper remains physically in the same

end of a given archive's sequence. See State Archival Service of the Russian Federation, Russian State Archive of the Economy/Gosudarstvennaia arkhivnaia sluzhba Rossiiskoi federatsii, Rossiiskii Gosudarstvennyi Arkhiv Ekonomiki, A research guide. 1: Guide to collections/ Putevoditel'. 1: Kratkii spravochnik fondov, American eds. William Chase and Jeffrey Burds, Russian eds. S. V. Prasolova,A.K.Sokolov,E.A.Tiurina(Moscow: Izdatel'stvo “Blagovest,” 1994).

37. Archivists refer to such odd-lot collections with a variety of idiosyncratic terms. I have found that neannotirovannye fondy usually gets the point across.

Depending on the archive in question, published and/or reading-room putevoditelimay or may not contain even partial lists of these odd-lot fondy. For a random published example of a Sovietera one that does, see Arkhivnyi Otdel UVD Tomskogo Oblispolkoma/Gosudarstvennyi Arkhiv Tomskoi Oblasti, Gosudarstvennyi Arkhiv Tomskoi Oblasti: Putevoditel' (Tomsk, 1960): 227243. These pages are a compilation entitled "Spisok fondov, khraniashchikhsia v gosudarstvennom arkhive Tomskoi oblasti,ne vkliuchennykh v osnovnuiu chast' putevoditelia."

38. The term spetspodfond is my own shorthand and may not be understood without explanation by Russians. In conversations with archivists I have found that podrazdeleniia fondov podlezhashchie spetskhraneniiu gets the idea across.

39. Thus RGIA-DV, f. r-2413 (Dal'kraiispolkom) is non-classified paper while f. r-2413sch (Dal'kraiispolkom - sekretnaia chast') is corresponding classified material.

40. Examples notably appear to include the classified material of the Sovet Trudy i Oborony/STO, which between 1917 and the tail end of the 1930s was intermittently an enormously important organ. During the Civil War period, STO as chaired by Lenin was an all-powerful emergency council more or less running what passed for central Soviet government. From May 1920 into early 1924 its publicly acknowledged responsibilities were thoroughly banal (weights and measures, inter-organizational financial arbitrage, etc.), and its influence over matters military was much diminished. Throughout the rest of the 1920s it was probably the crucial organ as far as economic policy, a good deal of which was connected intimately to non-operational defense considerations.

STO and the much better-known Sovnarkom SSSR shared roughly co-equal administrative status in the post-Lenin 1920s. From 1926 to 1930 they also shared Rykov as chair, with their respective deputy chairs on occasion meeting as a joint body. Sovnarkom SSSR was constitutionally the highest organ of Soviet (State) power with STO technically subordinate to it. The distinction was ignored in practice, unless STO in setting up a bureaucratic organ or commission needed the legal fiction of Sovnarkom approval, and STO had functional autonomy. Both bodies institutionalized Politbiuro and other TsK VKP(b) directives and also initiated their own work. 
archive as its parent fond, particularly at the regional and sub-regional levels I have worked at. Obviously, this enormously simplifies the business of tracking it down.

Note that although the unclassified and spetspodfond portions of a partly classified fond normally share the same archive, they may not share the same reading hall, archivists, or access procedures. For example, at GARF and at Rossiiskii Gosudarstvennyi Arkhiv Ekonomiki (RGAE), which cohabit the same group of buildings in Moscow, most spetspodfondy belong administratively to the spetskhranilishchalocated on the upper floors of the complex's courtyard entrances. ${ }^{41}$

The fundamental organizational unit of the spetspodfond was the classified opis'. Though the number of classified opisi theoretically could be large, my impressions are that the total in practice tended to be small. As a rule, classified opisi were numbered as part of the general sequence for their parent fond. They routinely were differentiated by postscripts indicating special-handling status. Normally this was a lower-case Cyrillic "s" for "sekretno."

Classified opisi did not appear in Soviet-period putevoditeli, card catalogs, opis' lists, and other such finding aids made privy to individuals lacking security clearance. With some exceptions, they still don't. This right-to-know legacy makes it hard to divine whether or not they exist for a particular fond. The difficulty is not helped by an atavistic tendency on the part of some archival staff to wait for researchers to push the subject. This of course will vary greatly according to the archive, the research agenda, the relative professional rank (and perhaps gender) of the parties involved, prevailing political winds, and so on. Nevertheless, my observation is that requests to see the opisi for any given fond unfortunately still may result in delivery of a stack of unclassified folders.

\section{University of Chicago}

Department of History

1126 E. 59th St.

Chicago IL 60626

e-mail: jab3@midway.uchicago.edu

From July 1925 on, STO's so-called "superintending” or "order-issuing” sessions (rasporiaditel'nye zasedaniia STO) were essentially the governmental/administrative face of the Komissiia Oborony pri Politbiuro TsK VKP(b). In April 1930 Stalin ousted Rykov from power, personally taking control of the KO PB TsK VKP(b) and appointing V. I. Molotov STO chair. As militarization increasingly dominated the Stalinist 1930s, so STO's already considerable administrative importance grew.

Unclassified STO paper in GARF, f. 5674 runs through 1932 and is mainly mundane. However, quite a few of the sanitized meeting records (protokoly) make fairly detailed passing reference to top-secret agenda items whose full texts were not revealed on right-to-know grounds. For example: op. 1, d. 19, 1. 213 is Protokol STO No. 263 ot 23.VII.26 g. Listed as punkt 35 is "Ob izmennii st. 1 razdela 1 postan. STO ot 2.VII.25 g. ob OKHRANE POGRANICHNOI POLOSY V VOENNOE VREMIA. d. No. st. 3-336 arkh. xix-4 utv. 24.VII.26 g. sov. sekretno." As of March 1996 the STO sub-fond was not available to me through the GARF spetskhranilishcha and evidently has been transferred to APRF.

41. GARF, f. 5515, op. 33s (see footnote 1) is one exception and there may well be more. The opis' for some reason appears in the main reading-hall card catalog and is obtainable not from a spetskhranilishche but via the main reading hall. 